\title{
Production of Biosurfactants by Actinomycetes Isolated from Hydrocarbon Contaminated Soils and Ikpoba River Sediments in Benin-City, Nigeria
}

\author{
${ }^{1}$ E.I Atuanya ${ }^{1} A$. Dunkwu-Okafor and ${ }^{2} U$. Udochukwu \\ 1Department of Microbiology, University of Benin, P.M.B 1154, Benin City, Nigeria. \\ 2Department of Biosciences, Salem University, Lokoja, Kogi State, Nigeria
} [*Corresponding author: rev.dr.ud@gmail.com]

\section{ABSTRACT}

The production of biosurfactants by Actinomycetes isolated from hydrocarbon contaminated soils and Ikpoba river sediments were evaluated. Soil samples were collected from mechanic workshops located in various parts of Benin City and Ikpoba river sediments. Physico-chemical analyses were performed. Isolation of Actnomycetes was done using starch casein agar incorporation with antibiotics incubated for 7 -10 days at $30^{\circ} \mathrm{C}$. Growth on mineral salt medium initiated the production of biosurfactants which was extracted by centrifugation and filtration followed by liquid extraction using chloroform: methanol (2:1v/v). Characterization and stability studies were conducted. The pH of the contaminated soil was $4.92+/-0.049$ while that of Ikpoba river sediments was $6.62+/-0.056$. The hydrocarbon contaminated soils had a higher concentration of surphur, nitrogen, potassium, sodium, magnesium and manganese compared to lkpoba River, but only chlorine concentration was higher in Ikpoba River. Aerobic Gram positive rods with extensive branching were observed confirming growth of Streptomyces sp. The result showed stability across different temperature ranges with no significant difference observed in the two sites in emulsification activity $(P>0.05)$. There was significant difference observed in the mean surface tension of the biosurfactants produced from the two sites across different temperature ranges with hydrocarbon contaminated soil having higher values $(\mathrm{P}>0.05)$. There was also significant surface tension difference between $\mathrm{pH} 2$ and $\mathrm{pH} 8$ $(P<0.05)$ suggesting higher activity within those ranges. The result also show stability across different salt concentrations and had foaming characteristics. Actinomycetes have complex enzymatic mechanism that aids hydrocarbon mineralization and thus increases the potential for biosurfactant production. These biosurfactants are stable across temperature ranges and are not majorly affected by salt concentration; this property aids its potential usage in decontamination of oil contaminated areas in the Niger Delta region of Nigeria and other countries.

Keywords: Biosurfactants, Actinomycetes, hydrocarbon contaminated soils and lkpoba river sediments

\section{INTRODUCTION}

The contamination of soil and groundwater with petroleum hydrocarbons is unfortunately a common phenomenon and has been causing serious environmental problems in Nigeria. The release of these contaminants to the environment including petroleum and petroleum based/derived products is one of the main causes of global contamination (Rahman et al., 2003). It is also a risk for human and animal health, since many of these contaminants are toxic and carcinogenic (Prabhu et al., 2003). Hydrocarbon molecules that are released into the environment are difficult to remove since they are absorbed to surfaces and are trapped in the water immiscible phase. Bioremediation has been considered and proven to be one of the best approaches and a suitable alternative to diminish the effects caused by hydrocarbon contamination of soil and water. This can be accomplished by using the metabolic capacity of microorganisms that can use hydrocarbon as source of carbon and energy, or that can be modified by co-metabolism and also for restoration of soil because the technology is cost effective and environmentally safe (Menezes et al., 2005). The efficiency of removal is directly related to the compounds chemical structure, bioavailability (concentration, toxicity, mobility 
and access) and physico-chemical conditions present in the environment (Cooper and Gondenenberg, 1987).

Actinomycetes are Gram positive bacteria with a distinctive feature of possessing filamentous hyphae that do not normally undergo fragmentation and produce asexual spore. They degrade enormous number and variety of organic compounds and are extremely important in the mineralization of organic matter (Margesin and Schinner, 2001). The success of bioremediation technology is also dependent upon a microbial ability to access the complex hydrocarbon mixture (Margesin and Schinner, 2001) which are compounds with low water solubility and thus not readily available to microorganisms. Because of this, bacteria consortia display a wide array of metabolic mechanisms for coping with the breakdown of oil components including the production of surface active agents and emulsifiers (Willumsen and Karlson, 1965). These agents are small surfactant molecules with hydrophilic and hydrophobic portions thereby providing amphipathic properties which enhances the bacterial growth and bioremediation rate.

Biosurfactants are structurally diverse group of surface active molecules synthesized by microorganisms. Virtually all surfactants are chemically synthesized (Banat, 1995). Much attention has been directed towards biosurfactants owing to their advantages such as low toxicity, high biodegradability, better environmental compatibility, high foaming capacity/capability, higher selectivity, specific activity at extreme temperature, $\mathrm{pH}$, salinity and ability to be synthesized them from removable food stocks (Bodour and Miller-Maier; Cameotra and Makkar, 1998). Surfactants accumulate at interphase between immiscible phases and can reduce surface and interfacial tensions. The significant reduction of interfacial tension caused by biosurfactant increases the solubility and emulsification of the immiscible phases and bioavailability of the insoluble substrate for the microorganisms (Banat et al., 2010). Biosurfactant with such surface properties make good candidates for enhanced oil recovery (EOR) (Banat et al., 2010). The most effective biosurfactant reduce surface tension (si) of water from 72 dyness $/ \mathrm{cm}$ to values in the range of $25-$ 30 dyness/cm (Ron and Rosenberg, 2001). They are also known to have therapeutic application (Rodrigues et al., 2006). Biosurfactants can also be used in bioremediation hydrocarbon contaminated soil and groundwater (Cameotra and Prothi, 2003). Recently, biosurfactant have been widely used in environmental protection including EOR, oil spill control, biogradation and detoxification of oil contaminated industrial effluents and soil (Cameotra and Prothi, 2003). Another most important application of biosurfactants is the stimulation of oil production in marginal wells that have approached the economic limitation of operation (Banat et al., 2010). Among the many classes of biosurfactants, lipopeptides represent a class of microbial surfactants with remarkable surface properties and biological activities such as surplus crude oil recovery.

\section{MATERIALS AND METHODS}

Soil samples were collected from hydrocarbon contaminated soils in mechanic workshops located in various parts of Benin City and river sediments were collected from Ikpoba River in Edo state. The samples were collected and stored in accordance with (Karthik et al., 2010). The physico-chemical parameters of the soil samples were analysed which include: $\mathrm{pH}$, temperature, total organic carbon, silt and sand composition, nitrate, Phosphorus, calcium, magnesium, sulphate, potassium, vanadium and moisture content of the soil samples (Kalra and Maynard, 1991; Adelekan and Abegunde, 2011; Maniyar et al., 2011). Isolation and enumeration of actinomycetes was done using Starch-Casein Agar. Soil samples were serially diluted $\left(10^{-6}\right)$ and $1 \mathrm{ml}$ of sample from each plated on starch casein agar. The colonies which showed morphological difference were selected and purified. The plates were incubated for $7-10$ 
days at $30^{\circ} \mathrm{C}$ (Zaki et al., 2013; Lakshmipathy et al., 2010). The ability of biosurfactant producing actinomycetes to utilize hydrocarbon was determined by measuring the turbidity of the actinomycetes inoculation into the Bushnell Hass broth containing crude oil as carbon source of mineral salt medium (Lakshmipathy et al., 2010).

\section{Production and Extraction of Biosurfactants}

The samples selected were inoculated in a $250 \mathrm{ml}$ Erlenmyer flask containing $250 \mathrm{ml}$ sterile mineral salts medium consisting of $\left(\mathrm{Na}_{2} \mathrm{HPO}_{4} 6 \mathrm{~g}\right.$, $\mathrm{KH}_{2} \mathrm{PO}_{4} 3 \mathrm{~g}, \mathrm{NH}_{4} \mathrm{CL} 1 \mathrm{~g}, \mathrm{MgSO}_{4} .7 \mathrm{H}_{2} \mathrm{O} 0.24 \mathrm{~g}$ and $\mathrm{CaCL}_{2} 0.01 \mathrm{~g}$, Daeto-agar $15 \mathrm{~g}$, distilled water (I) with $20 \mathrm{~g}$ glucose $\mathrm{pH} 7$ soybean oil $0.19 \mathrm{~g}$ as carbon source, $5.0 \mathrm{~g}$ glutamic acid. Trace elements solution containing (g/l): $\mathrm{ZnSO}_{4} .7 \mathrm{H}_{2} \mathrm{O}$ 2.32; $\mathrm{MnSO}_{4}$. $4 \mathrm{H}_{2} \mathrm{O}$ 1.78; $\mathrm{H}_{3} \mathrm{BO}_{3}$ 0.56; $\mathrm{CySO}_{4}$. $5 \mathrm{H}_{2} \mathrm{O}$ 1.0; $\mathrm{Na}_{2} \mathrm{MO}_{4}$. $2 \mathrm{H}_{2} \mathrm{O}$ 0.39; $\mathrm{CaCL}_{2}$. $6 \mathrm{H}_{2} \mathrm{O}$ 0.42; EDTA 1.0; $\mathrm{NiCL}_{2}$. $6 \mathrm{H}_{2} \mathrm{O} 0.004$ and $\mathrm{KI} 0.66$; and Bushnell Hass medium with $3 \%$ forcados blend crude oil as carbon source. The broth cultures were incubated on a reciprocal shaker at 120rpm for 5-7 days at $30^{\circ} \mathrm{C}$ (Sabina et al., 2010; Moliterni et al., 2012). The biosurfactant was extracted from the culture by centrifugation and filtration. The cell free broth was extracted by liquid - liquid extraction from the cell-free supernatant using mixture of chloroform: methanol $(2: 1 \mathrm{v} / \mathrm{v})$. The extracts was divided in rotating evaporator, weighed and quantified (Jain et al., 1991).
Biosurfactant Characterization
Surface tension measurement: The surface tension of the biosurfactant was measured by the ring method using the Du-Nony tension meter (Kruss type 8451) at room temperature equipment with plate and samples with cell culture broths. A measurement of surface tension from distilled water was used as negative control. The concentration at which micelles began to form was represented as the CMC. At the CMC, a sudden change in surface tension was observed. The CMC was determined by plotting the surface tension as a function of biosurfactant concentration and surface tension at this point was designated as $7 \mathrm{cmc}$ (Khopade et al., 2012).

\section{Emulsification activity and foaming properties: The foaming properties were evaluated by monitoring the stability of the foam formed by hand shaking of the crude biosurfactant for 2 hours. Emulsification index of culture sample was determined by adding $2 \mathrm{ml}$ of a hydrocarbon to the same amount of culture/same volume of biosurfactant in a graduated screw cap test tube and then vortexed for $2 \mathrm{~min}$ and left 24hours. The $\mathrm{E}_{24}$ index was given as a percentage of height of emulsified layer $(\mathrm{mm})$ divided by the height of the liquid column (mm) (Khopade et al., 2012).}

$$
E_{24}(\%)=\frac{\text { Total height of the emulsified layer } \times 100 \%}{\text { Height of total evolution }}
$$

\section{Stability Characterization}

To determine the thermal stability of the biosurfactant, about $4 \mathrm{ml}$ of the culture supernatant were stored at 4 and $25^{\circ} \mathrm{C}$ heated at $70{ }^{\circ} \mathrm{C}, 100^{\circ} \mathrm{C}$ and $2{ }^{\circ} \mathrm{C}$ for $15 \mathrm{mins}$ and then cooled to room temperature. The surface and $E_{24}$ value of each treatment will be performed as described (Techaoei et al., 2007). The $\mathrm{pH}$ change effect was determined by adjusting the culture supernatural with acid (IN HCL) or (IN
$\mathrm{NaOH}$ ) to $\mathrm{pH}$ values ranging from 1-10 prior to filter sterilization to monitor the surface tension and $\mathrm{E}_{24}$ are measured and determined (Techaoei et al., 2007). The effect of salinity was measured by adding $5-20 \% \mathrm{NaCL}$ then the sample was subjected to surface tension test measured at $\mathrm{E}_{24}$.

Biochemical and Antimicrobial Activity

The protein content of surfactant was estimated using biuret and ninhydrin method and lipid 
content estimate by isolated and purification method, total carbohydrates were calculated using molish test. The crude biosurfactant was tested for antimicrobial activity using diffusion method and area of zone was calculated. Active compounds were tested against Escherichia coli, Bacillus stubtilis, Pseudomonas aeruginosa, Staphylococcus aureus and Candida albican.

\section{RESULTS}

The results from this study showed a wide range of difference in the physic-chemical parameters of the hydrocarbon contaminated soil and lkpoba River sediment which influenced the production of biosurfactant by actinomycetes (Table 1). The emulsification activity of the biosurfactants for $\mathrm{pH}$, salt concentration and temperature were observed and recorded in (Table 2, 3, and 4). The surface tension of the biosurfactants for temperature, salt concentration and $\mathrm{pH}$ were recorded in (Table 5, 6, and 7). Table 8, shows the result of the biochemical test for the biosurfactant and the cultural, morphological and biochemical test for Streptomyces sp. was shown in Table 9.

\section{DISCUSSION}

There was extensive branching of the mycelium observed in the Petri dish which was observed to be Gram positive rod, non motile, oxidase negative and catalase positive. The organism grew on mineral salt medium incorporated with crude oil. The organism was identified as Streptomyces sp. (Karthik et al., 2010). Biosurfactant production was indicated by the presence of foam while on the rotator shaker (Moussa et al., 2006; Khopade et al., 2012). Biosurfactant production was independent on growth phase (Chakraborty et al., 2009). There was no significant difference in the mean emulsification activity of the biosurfactants produced from the two sites across different $\mathrm{pH}$ $(p>0.05)$, but with increase in $\mathrm{pH}$ between 2 and 8 , there was significant difference in the emulsification activity from the extracted biosurfactants from the two sites (Table 2). A significant difference was observed in the mean $\mathrm{pH}$ surface tension of the biosurfactants

Table 1: Physico-chemical qualities of Hydrocarbon contaminated soil and Ikpoba River

\begin{tabular}{|c|c|c|}
\hline $\begin{array}{l}\text { Parameter } \\
\text { s }\end{array}$ & $\begin{array}{l}\text { Mechanic } \\
\text { Workshop soil }\end{array}$ & $\begin{array}{l}\text { Ikpoba } \\
\text { River } \\
\text { Sediment }\end{array}$ \\
\hline $\mathrm{pH}$ & $6.62 \pm 0.056$ & $4.92 \pm 0.049$ \\
\hline $\mathrm{CL}-\mathrm{mg} / \mathrm{kg}$ & $15.89 \pm 0.131$ & $6.98 \pm 0.038$ \\
\hline $\mathrm{SO}_{4}{ }^{2-} \mathrm{mg} / \mathrm{kg}$ & $1.35 \pm 0.01$ & $\begin{array}{l}3.717 \pm 0.02 \\
3\end{array}$ \\
\hline $\mathrm{NO}_{3}-\mathrm{mg} / \mathrm{kg}$ & $3.03 \pm 0.021$ & $8.34 \pm 0.436$ \\
\hline $\mathrm{PO}_{4}^{3-} \mathrm{mg} / \mathrm{kg}$ & $0.13 \pm 0$ & $0.36 \pm 0$ \\
\hline $\mathrm{Na}^{+} \mathrm{mg} / \mathrm{kg}$ & $1.58 \pm 0.01$ & $4.35 \pm 0.02$ \\
\hline $\mathrm{K}^{+} \mathrm{mg} / \mathrm{kg}$ & $2.97 \pm 0.025$ & $8.16 \pm 0.044$ \\
\hline $\mathrm{Ca}^{2+} \mathrm{mg} / \mathrm{kg}$ & $3.95 \pm 0.031$ & $9.97 \pm 0.055$ \\
\hline $\mathrm{Mg}^{2+} \mathrm{mg} / \mathrm{kg}$ & $1.02 \pm 0.01$ & $2.81 \pm 0.017$ \\
\hline $\mathrm{Fe}^{3+} \mathrm{mg} / \mathrm{kg}$ & $29.97 \pm 0.025$ & $\begin{array}{l}26.38 \pm 0.14 \\
2\end{array}$ \\
\hline $\mathrm{Zn}^{2+} \mathrm{mg} / \mathrm{kg}$ & $4.97 \pm 0.040$ & $9.16 \pm 0.041$ \\
\hline $\mathrm{Mn}^{2+} \mathrm{mg} / \mathrm{kg}$ & $1.22 \pm 0.01$ & $3.35 \pm 0.02$ \\
\hline $\mathrm{Cu}^{2+} \mathrm{mg} / \mathrm{kg}$ & $0.56 \pm 0$ & $1.54 \pm 0$ \\
\hline $\mathrm{Ni}^{2+} \mathrm{mg} / \mathrm{kg}$ & $1.35 \pm 0.01$ & $3.72 \pm 0.02$ \\
\hline $\mathrm{Cd}^{2+} \mathrm{mg} / \mathrm{kg}$ & $0.1 \pm 0$ & $0.72 \pm 0.006$ \\
\hline $\mathrm{V}^{2+} \mathrm{mg} / \mathrm{kg}$ & $0.13 \pm 0$ & $0.47 \pm 0$ \\
\hline $\mathrm{Cr}^{6+} \mathrm{mg} / \mathrm{kg}$ & $0.26 \pm 0$ & $0.73 \pm 0$ \\
\hline $\mathrm{Pb}^{2+} \mathrm{mg} / \mathrm{kg}$ & $3.23 \pm 0.025$ & $8.89 \pm 0.049$ \\
\hline $\mathrm{Hg}^{+} \mathrm{mg} / \mathrm{kg}$ & $<0.001$ & $<0.001$ \\
\hline As mg/kg & $<0.001$ & $0.11 \pm 0.025$ \\
\hline $\mathrm{EC}$ us/cm & $66.91 \pm 0.541$ & $\begin{array}{l}40.85 \pm 0.02 \\
6\end{array}$ \\
\hline TDS ppm & $33.95 \pm 0.273$ & $\begin{array}{l}20.92 \pm 0.11 \\
6\end{array}$ \\
\hline T-Carbon \% & $0.58 \pm 0.058$ & $0.33 \pm 0.038$ \\
\hline $\begin{array}{l}\text { T-Nitrogen } \\
\%\end{array}$ & $0.06 \pm 0$ & $0.74 \pm 0.056$ \\
\hline
\end{tabular}


Temperature majorly affects the biosurfactant surface tension. This thermal studies show that the biosurfactant is thermally stable across the temperature range studied (Zaki et al., 2013). Khopade et al. (2012) reported that the applicability of surfactants in several fields depends on its stability at different temperature and $\mathrm{pH}$. Heating of the biosurfactant to $100^{\circ} \mathrm{C}$ caused no significant effect on the biosurfactant performance. This activity indicates its possible usefulness in food industries and pharmaceuticals where heating to stability is of paramount importance (Abouseoud et al., 2008; Mulligan and Gibbs, 1989). Ikpoba River had a slightly higher temperature compared to the hydrocarbon contaminated site. There was no significant difference in emulsification activity of the biosurfactant, although there was an increase from $70^{\circ} \mathrm{C}$ to $100^{\circ} \mathrm{C}$ and slightly decreased when the temperature reach $121^{\circ} \mathrm{C}$ (Table 4). Boisurfactants are generally stable across salt concentration ranges of $2-20 \%$ and that salt concentration does not affect biosurfactant emulsification (Khopade et al., 2012; Sarubbo et al., 2007). The biosurfactant has stability at an alkaline $\mathrm{pH}$ and slightly higher makes it a useful tool in the bioremediation of marine crude oil spill (Prieto et al., 2008). The produced boisurfactant in this research possessed foaming ability, amino acids, peptides, fats and oil without carbohydrate.

Table 2: Emulsification Activity change on $\mathrm{pH}$

\begin{tabular}{ccc}
\hline pH & $\begin{array}{c}\text { Emulsification Activity } \\
\left(E_{24}\right)(\%) \\
\text { Mechanic Workshop } \\
\text { soil }\end{array}$ & $\begin{array}{c}\text { Ikpoba River } \\
\text { Sediment }\end{array}$ \\
\hline 2 & 23 & 30 \\
4 & 28 & 34 \\
7 & 34 & 36 \\
8 & 36 & 46 \\
11 & 32 & 38 \\
\hline
\end{tabular}

Table 3: Emulsification Activity change on salt concentration

\begin{tabular}{ccc}
\hline \multicolumn{3}{c}{ Emulsification Activity $\left(\mathrm{E}_{24}\right)(\%)$} \\
$\begin{array}{c}\text { Salt } \\
\text { Content } \\
(\%)\end{array}$ & $\begin{array}{c}\text { Mechanic } \\
\text { Workshop soil }\end{array}$ & $\begin{array}{c}\text { Ikpoba River } \\
\text { Sediment }\end{array}$ \\
\hline 2 & 39 & 35 \\
8 & 35 & 38 \\
15 & 34 & 36 \\
\hline
\end{tabular}

Table 4: Emulsification Activity on Temperature

\begin{tabular}{ccc}
\hline \multicolumn{3}{c}{ Emulsification Activity $\left(\mathrm{E}_{24}\right)(\%)$} \\
Temperature & $\begin{array}{c}\text { Mechanic } \\
\text { Workshop soil }\end{array}$ & $\begin{array}{c}\text { Ikpoba River } \\
\text { Sediment }\end{array}$ \\
\hline 70 & 30 & 32 \\
100 & 27 & 30 \\
121 & 25 & 27 \\
\hline
\end{tabular}

Table 5: Surface Tension change on Temperature

\begin{tabular}{|c|c|c|}
\hline \multicolumn{3}{|c|}{ Surface Tension (dynes/cm) } \\
\hline $\begin{array}{c}\text { Temperature } \\
\left({ }^{\circ} \mathrm{C}\right)\end{array}$ & $\begin{array}{c}\text { Mechanic } \\
\text { Workshop soil }\end{array}$ & $\begin{array}{c}\text { Ikpoba River } \\
\text { Sediment }\end{array}$ \\
\hline 70 & 117 & 81 \\
\hline 100 & 105 & 70 \\
\hline 121 & 99 & 65 \\
\hline \multicolumn{3}{|c|}{$\begin{array}{l}\text { Table 6: Surface Tension change on Salt } \\
\text { concentration }\end{array}$} \\
\hline \multicolumn{3}{|c|}{ Surface Tension (dynes/cm) } \\
\hline $\begin{array}{c}\text { Salt } \\
\text { content } \\
(\%)\end{array}$ & $\begin{array}{c}\text { Mechanic } \\
\text { Workshop soil }\end{array}$ & $\begin{array}{l}\text { Ikpoba River } \\
\text { Sediment }\end{array}$ \\
\hline 2 & 111 & 83 \\
\hline 8 & 104 & 76 \\
\hline 15 & 107 & 79 \\
\hline
\end{tabular}


Table 7: Surface Tension change on $\mathrm{pH}$

\begin{tabular}{|c|c|c|}
\hline \multicolumn{3}{|c|}{ Surface Tension (dynes/cm) } \\
\hline $\mathrm{pH}$ & $\begin{array}{c}\text { Mechanic Workshop } \\
\text { soil }\end{array}$ & $\begin{array}{c}\text { Ikpoba River } \\
\text { Sediment }\end{array}$ \\
\hline 2 & 119.5 & 99.1 \\
\hline 4 & 125.4 & 103.7 \\
\hline 7 & 139.9 & 110.4 \\
\hline 8 & 151.6 & 114.95 \\
\hline 10 & 160.4 & 117.2 \\
\hline
\end{tabular}

Table 8: Results of Biochemical Test for Biosurfactant

\begin{tabular}{lc}
\hline Test & Remarks \\
\hline Molisch test & - \\
Buiret test & - \\
Ninhydrin test & + \\
Fats and oils & + \\
\hline
\end{tabular}

Table 9: Cultural, Morphological and Biochemical

\section{CONCLUSION}

Actinomycetes have the potentials of producing a wide range of beneficial compounds. Actinomycetes have complex enzymatic mechanism that aids hydrocarbon mineralization and thus increases the potential for biosurfactant

\section{REFERENCE}

Abouseoud, M., Maachi, R., Amrane, A., Boudergua, D. and Nabi, A. (2008). Evaluation of different carbon and nitrogen sources in production of biosurfactant by Pseudomonas fluorescens. Desalination. 233: 143-151

Adelekan, B. A. and Abegunde, K.D. (2011). Heavy Metals Contamination of Soil and Groundwater at Automobile Mechanic Villages in Ibadan, Nigeria. International Journal of The Physical Sciences. 6(5): 1045-1058
Test of Streptomyces sp. isolated from Ikpoba River sediment and Mechanic Workshop soil in Benin City.

Cultural

Arial spore colour white

Spore surface Smooth

Mycelium Colony Extensive branching

Colony

Power, granular

and velvety

\section{Mophology}

Motility Non motile

Oxygen requirement Aerobic

Biochemical

Gram staining Positive

Catalase test Positive

Hydrocarbon

Utilization

Negative

Arabinose, fructose Positive

Probable isolate Streotomyces sp.

production. The biosurfactants produced are stable across temperature ranges and are not majorly affected by salt concentration. This property may aid its potential use in decontamination of oil contaminated areas in the Niger Delta region of Nigeria and other countries.

Banat, I. M. (1995). Characterization of Biosurfactants and their use in Pollution removal: State of the Art. Acta Biotechnologyca. 15: 251-267

Banat, I. M., Franzetti, A., Gandolfi, I., Bestetti, G., Martinotti, M. G., Fracchia, L., Smyth, T. J and Marchant, R. (2010). Microbial Biosurfactants Production, Applications and Future Potential. Applied Microbiology and Biotechnology. 87(2): 427-444

Bodour, A.A and Miller-Maier, R. (1998). Application of a Modified Drop-Collapse Technique for Surfactant Quantification 


\section{Nigerian Journal of Basic and Applied Science (December, 2016), 24(2): 45-52}

and Screening of BiosurfactantProducing Microorganisms. Journal of Microbiology Methods. 32: 273-280

Cameotra, S. S. and Makkar, R. S. (1998). Synthesis of Biosurfactants in Extreme Conditions. Applied Microbiology And Biotechnology. 53:495-508

Cameotra, S.S and Prothi, V. (2003). Effects of Nutrients on Optimal Production of Biosurfactants by Pseudomonas putida-a gujarat Oil Field Isolate. Journal of Surfactants And Detergents. 6: 65-68

Chakraborty, S. Khopade, A., Kokare, C., Mahadik, K. and Chopade, B. (2009). Isolation and characterization of noval aamylase from marine streptomyces $\mathrm{sp}$. D1. Journal of Molecular Catalysis B. 58: 17-23

Cooper, D.G and Gondenenberg, B. G. (1987). Surface-Active Agents from two Bacillus species. Applied Environmental Microbiology. 53: 224-229

De Oliveira Camargo, F. A., Okeke, B. C. and Frankebberger, W. T. (2005). Diversity of Biosurfactant production during Diesel Biodegradation by mixed Microbial Consortia selected from Polluted Soils. International Journal of Environmental Research. 160: 249-255.

Jain, D.K., Collins-Thomson, D. L., Lee, H. and Trevors, J.T. (1991). A drop collapsing test for screening surfactant producing microorganism. Journal of Microbiological Methods. 13: 271-279.

Karthik, L., Kumar, G., Venkata, K. and Rao, B. (2010). Comparison of Methods and Screening of Biosurfactant Producing Marine Actinobacteria Islated from Nicobar Marine Sediment. The LLOAM Journal. 1(2): 34-38.

Kalra, Y.P. and Maynard, D. G. (1991). Methods Manual for Forest Soil and Plant Analysis. Northwest Region, USA. pp125.

Khopade, A., Ren, B., Liu, X., Mahadik., Nzhang, L. and Kokare, C. (2012). Production of biosurfactant from marine Streptomyces species B3. Journal of Colloid And Interface Science. 367: 311-318

Lakshmipathy, T. D., Prasad, A. and Kannabiran, K. (2010). Production of Biosurfactant and Heavy Metal resistance activity of Streptomyces sp. VITDDK3-a novel halo tolerant Actinomycetes isolated from Saltpan Soil. Advances in Biological Research. 4(2): 108-115

Margesin, R. And Schinner, F. (2001). Biodegradation and Bioremediation of Hydrocarbon in Extreme Environment. Apllied Microbiology And Biotechnology. 56:650-663

Maniyar, J. P., Doshi, V. D., Bhuyan, S.S. and Mujumdar, S.S. (2011). Bioemulsifer Production by Streptomyces sp. S22 Isolated from Garden Soil. Indian Journal of Experimental Biology. 49(4): 293-297.

Moliterni, E., Gomez, R., Rodriguez, L., Fernandez, F. S. and Villaseenor, J. (2012). Biosurfactant production during diesel biodegradation by mixed microbial consortia isolated from a polluted soil. International Journal of Environmental Research. 6(3): 751-760.

Moussa, T. A.A., Ahmed, G.M. and Abdel-Hamid, S.S. (2006). Optimization of cultural conditions for biosurfactant production from Norcadia amarae. Journal of Applied Science Research. 2(11): 844850.

Mulligan, C.N. and Gibbs, B. F. (1989). Correlation of nitrogen metabolism with biosurfactant production by Pseudomonas aeruginosa. Applied Environmental Microbiology. 55: 30163019.

Prieto, L. M., Michelon, M., Burkert, J. F. M., Kalil, S. J. and Burkert, C. A. V. (2008). The production of rhamnolipid by a Pseudomonas aeruginosa strain isolated from a southern coastal zone in brazil. Chemosphere. 71: 1781-1785.

Prabhu, Y. And Phale, P. (2003). Biodegradation of Phenanthrene by Pseudomonas sp. Strain PP2: Novel Metabolic Pathway, 
Role of Biosurfactant and Cell Surface Hydrophobicity in Hydrocarbon Assimilation. Applied Microbiology and Biotechnology. 61: 342-351.

Rahman, K., Rahman, T., Korkoutas, Y., Petsas, I., Marchant, R., and Banat, I. (2003). Enhanced Bioremediation of $n$-alcane in Petroleum Sluge using Bacteria Consortium amended with Rhamnolip and Micronutrients. Bioresource Technology. 90: 159-168.

Ron, E. Z. and Rosenberg, E. (2001). Natural Roles of Biosurfactants. Environmental Microbiology. 3(4): 229-236.

Rodrigues, L. R., Teixeira, J.A., Varder Mei, H. C. and Oliviera, R. (2006). Physiochemical and Functional Characterization of $\mathrm{A}$ Biosurfactant Produced by Lactococcus Lactis 53. Colloids Surfactants B. 49: 79-86.

Sabina, V. R., Portillo-Ruiz, M. C., BallinasCasarrubias, M.L., Torres-Munoz, J.V., Rivera-Chavira, B.F. and NevarezMoorillion, G. V. (2010). Selection of biosurfactant/bioemulsifier producing Bacteria from Hydrocarbon Contaminated Soil. Brazilian Journal of Microbiology. 41: 668-675.

Sarubbo, L.A., Farias, C. B.B. and Campos Takaki, E. M. (2007). Co-utilization of canole oil and glucose on production of a surfactant by Candida lipolytica. Brazilian Journal of Microbiology. 54: 68-73.

Techaoei, S., Leelapornpisid, P., Santiarwarn, D. and Lumyong, S. (2007). Preliminary screening of biosurfactant producing microorganisms isolated from hot spring and garges in northern Thailand. KMITL. Science Technology Journal. 7:38-43.

Willumsen, P. A. and Karlson, F. L. (1965). Use of Antibiotics for Selective Isolation and Enumeration of Actinomycetes in Soil. Journal of General Microbiology. 7: 415423

Zaki, S.A., Elkady, M. F., S. and Abd-El-Haleem, (2013). D. Characterization and Flocculation Properties of a
Carbohydrate Bioflocculant from a newly Isolated Bacillus velezensis 40B. Journal of Environmental Biology. 34:51-58. 